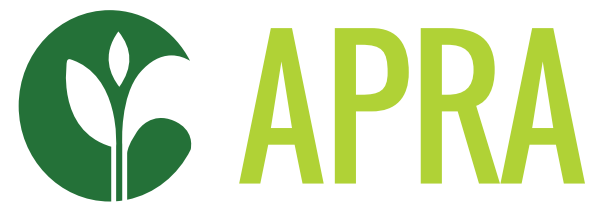

Agricultural Policy Research in Africa

\title{
EXPLAINING THE WEAKNESS OF ASSOCIATIONAL LIFE IN OIL PALM GROWING COMMUNITIES IN SOUTHWESTERN GHANA
}

Dorothy Takyiakwaa, Prince Selorm Kodzo Tetteh and Kofi Takyi Asante 


\section{CONTENTS}

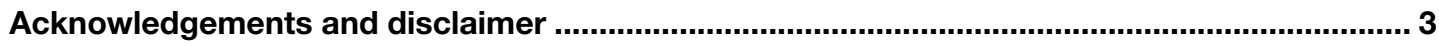

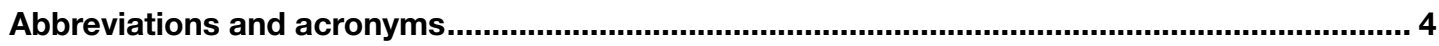

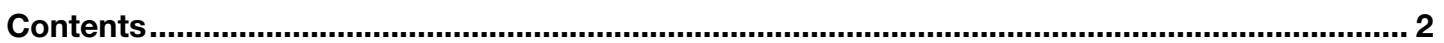

List of tables

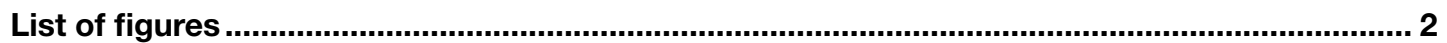

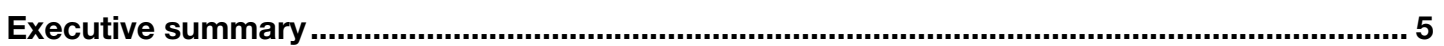

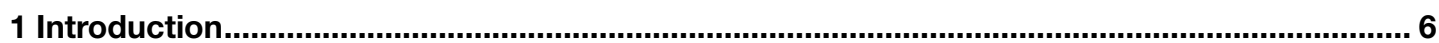

2 Agricultural commercialisation and smallholder livelihoods ................................................. 7

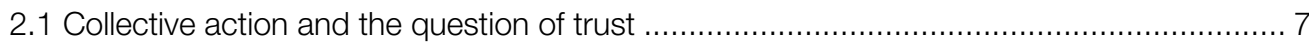

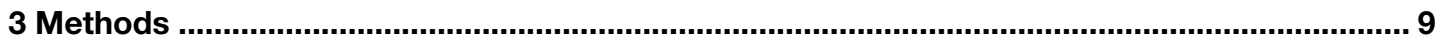

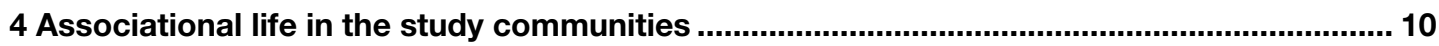

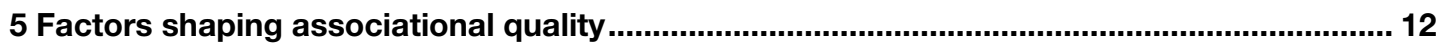

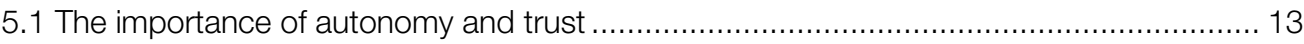

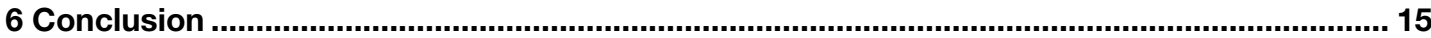

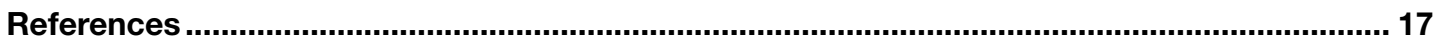

\section{List of tables}

Table 3.1: Some characteristics of study communities .................................................... 9

\section{List of figures}

Figure 6.1: Graphical presentation of argument. 


\section{ACKNOWLEDGEMENTS AND DISCLLAIMER}

This research was conducted under the Agricultural Policy Research in Africa (APRA) programme. The authors would like to acknowledge the financial and technical support from the Institute of Development Studies (IDS).

Dorothy Takyiakwaa is a lecturer at the Department of Sociology and Anthropology, University of Cape Coast. Prince Selorm Kodzo Tetteh is pursuing an MA degree in Political Science at the University of Southern Mississippi. Kofi Takyi Asante is a research fellow at the Institute of Statistical, Social and Economic Research at the University of Ghana.

This working paper is funded with UK aid from the UK government (Foreign, Commonwealth \& Development Office - FCDO, formerly DFID). The opinions are the authors and do not necessarily reflect the views or policies of IDS or the UK government. 


\section{ABBREVIATIONS AND ACRONYMS}

AEA

agricultural extension agents

APRA

Agricultural Policy Research in Africa

B-BOVID

Building Business on Value, Integrity and Dignity

BOPP

Benso Oil Palm Plantation

FBO

farmer-based organisation

FGD

focus group discussion

MoFA

Ministry of Food and Agriculture

NGL

Norpalm Ghana Limited

NGO

non-governmental organisation

OPC

oil palm company 
As the second most important industrial crop in Ghana, oil palm holds the potential of improving farmers' livelihoods and alleviating rural poverty. However, this transformative potential is unrealised because most smallholders are unable to reap the benefits of commercialisation owing to lack of resources. For such farmers, collective action through farmer-based organisations (FBOs) could provide a pathway to inclusive participation in agricultural commercialisation. There is ample evidence in the literature that collective action can help smallholders gain access to credit, improved inputs, or even networks of social support. Thus, collective action is widely recognised as a viable pathway out of poverty for the agrarian poor. For poor farmers who lack the capacity to independently respond to the risks of commercialisation, participating in collective action schemes such as FBOs can help overcome the constraints that their individual resources would be insufficient for by reducing transaction costs, enabling access to inputs and credit, and overcoming market constraints.

This paper draws on qualitative data collected as a follow-up to the quantitative baseline survey conducted as part of the Ghana Work Stream 1 package of the Agricultural Policy Research in Africa (APRA) consortium in the Ahanta West and Mpohor districts of the Western Region. Building on preliminary insights from the quantitative study, we sampled five communities based on the dominant marketing outlets identified in the quantitative data - i.e., commercial engagement with Benso Oil Palm Plantation (BOPP), Norpalm Ghana Ltd. (NGL), Building Business on Values, Integrity, and Dignity (B-BOVID), and independent sales (on the open market or to artisanal processors). In each community, we sampled at least five heads of household. At the household level, we conducted interviews with each household head, which lasted for an average of one hour, and complemented these with shorter interviews with spouses and dependents. We also conducted two focus group discussions (FGDs) separately for males and females in each community. At the district level, we conducted expert interviews with district agricultural officers of the Ministry of Food and Agriculture (MoFA). Finally, we interviewed management-level employees at BOPP, NGL, and B-BOVID.
In all five communities, FBOs were either weak or non-existent. Indeed, we find that economic relations between farmers tend to be more individualised than one would expect to find in rural communities, resulting from the personal or financial cost of cooperation, unrealistic expectations of FBOs, and mistrust stemming from poor internal governance. Without any strong association, farmers are left with no organisational vehicle to collectively negotiate prices or acquire productivity-enhancing technology. Wealthier farmers are able to overcome this disadvantage by independently pooling resources with similarly endowed farmers to engage in income-enhancing activities, such as sharing the cost of direct sales to the oil palm companies (OPCs), or investing in processing technology. This situation is particularly disadvantageous for poorer farmers, because it hinders their ability to benefit from the advantages of agricultural commercialisation. In particular, a strong association or cooperative could have enabled them to overcome the lack of resources which limits their individual abilities for profitable market participation.

The expectation that FBOs can help poor farmers overcome obstacles to profitable commercialisation is based on analytical insights from the collective action and social capital literatures, which postulate that the social networks contain a rich store of resources which can be tapped into to improve individual lives and empower communities. However, our findings indicate that material hardship is an important obstacle in many of these abortive collective endeavours. Although they are aware of the benefits of effectively nurturing social networks and collective action, lack of material autonomy forces them to make short term survival decisions. This lack of autonomy undermines their ability to generate or nurture trust. Without trust, FBOs lack any means of ensuring the implementation of collective decisions requiring voluntaristic compliance. The resulting mistrust further engenders disinterest and apathy in the affairs of the association. This can result in a vicious circle, where wealth disparities widen in a community because the material prerequisites for participating in livelihood-enhancing collective schemes end up excluding exactly those who need such schemes the most. 


\section{INTRODUCTION}

Agricultural commercialisation provides a pathway out of poverty for rural households by increasing access to improved inputs, and helping farmers increase their incomes by scaling up their operations. Beyond these positive effects at the micro level, agricultural commercialisation is expected to lead to positive externalities in the local agrarian economy, ultimately contributing to transformation at the community level (Poulton, 2017). However, after over a century of commercialised cultivation of oil palm production, the expected improvements in the livelihoods of smallholder farmers and the national economy have not materialised. The reasons for this are multifarious, ranging from historical and political reasons that inhibit the effectiveness of policies targeting the sector (Teye and Torvikey, 2018; Asante, 2021), to communityand household-level factors that explain why some smallholder households are unable to realise the welfare-enhancing potential of participating in oil palm commercialisation (Dzanku et al., 2020; Saha, SabatesWheeler and Thompson, 2021).

These studies suggest that the ability of agricultural commercialisation to improve farmers' livelihoods does not occur automatically. Dzanku et al. (2020) found that smallholder oil palm farmers who derived the most benefit from agricultural commercialisation were already better off on measures such as farm size, tenure security, income from off-farm employment, and asset-ownership. Indeed, asset holding is crucial in Saha, Sabates-Wheeler and Thompson's (2021, p. 3) definition of smallholders' 'capacity for commercialisation' because it shapes their ability 'to respond to the risks from commercialisation'.

For poor farmers who lack the capacity to independently respond to the risks of commercialisation, participating in collective action schemes such as FBOs can help them overcome the constraints that their individual resources would be insufficient for. There is ample evidence in the literature that collective action can help smallholder farmers to overcome obstacles to commercialisation by reducing transaction costs, enabling access to inputs and credit, and overcoming market constrains (Francesconi \& Ruben, 2007; Markelova et al., 2009; Nyikahadzoi et al., 2011; Fischer \& Qaim, 2014; Kibirige, 2016).
However, collective action schemes are not always an option for the poorest farmers. We find that whereas FBOs can serve as conduits of important market information and can help farmers to access input and output markets, as well as training and other services, they were either weak or non-existent in the study communities. This situation is partially accounted for by the inability of poorer farmers to meet their financial obligations to their associations, as well as mistrust stemming from a history of unaccountable leadership of these associations. Under these circumstances, cooperation tends to be limited to small groups of betteroff farmers, where it is easier to ensure compliance.

This paper examines smallholder farmers' participation in farmer-based associations in five oil palm growing communities in the Western Region. We examine the roles these organisations (are expected to) play and the factors which affect their abilities to do so effectively. A central insight from our study can be summarised in the quip: poverty is the cause of poverty, i.e., the poor, who stand to gain the most from trustful relations, are unable to nurture trust because resource constraints compel them to take short-term decisions, which in turn undermine collective action. The ultimate result is that farmers in the study communities are forced to participate in the market on an extremely individualistic bases, without any protection from market or state failures.

The rest of the paper is organised as follows: the next section reviews the literature on agricultural commercialisation and collective action. The third section briefly describes the methods, and the fourth section presents the findings. The first part of the findings examines the quality of social relations in the study communities, paying particular attention to issues of trust, or the lack thereof, while the second part focuses on the strength of associational life. The final section concludes with brief reflections on social capital and the material bases of trust. 


\section{AGRICULTURAL GOMMERCIALISATION AND SMALLHOLDER LIVELIHOODS}

According to Poulton (2017, p. 4) agricultural commercialisation 'occurs when agricultural enterprises and/or the agricultural sector as a whole rely increasingly on the market for the sale of produce and for the acquisition of inputs, including labour.' To this end, the market drive plays a pivotal role in the defining features of agricultural commercialisation. This involves redirecting productive efforts from semisubsistence towards production for local, national, and international markets (Dorward and Kydd, 2002).

The drive for agricultural commercialisation is expected to result in improved livelihoods at the household and national levels (von Braun, 1995; Kibirige, 2016; Poulton, 2017; Cazzuffi et al., 2020), and in some developed and developing countries has proven to be efficient in driving industrial and economic growth. For instance, Kibirige (2016) observed that large-scale agricultural commercialisation, which employs the use of sophisticated technologies and modern machinery, has contributed largely to economic and industrial growth of developed countries. Successful agricultural commercialisation directly creates employment and augments agricultural labour productivity (von Braun, 1995). Large-scale farms and their associated processing operations often create spill-over effects or employment for members of smallholder households in surrounding areas (Poulton, 2017; Cazzuffi et al., 2020)

However, there are several barriers that prevent smallholder farmers from reaping the benefits of agricultural commercialisation. Rooted in lack of financial means, these barriers include small farm sizes, poor cash flow, and lack of access to improved inputs, among others (Arias et al., 2013). In general, smallholder farmers are unable to make the investment necessary to scale up production because they are denied credit facilities based on their 'household demographics, socioeconomic and farm characteristics' as well as their inability to provide collateral (Mutero, Munapo and Seaketso, 2016, p. 41). Furthermore, smallholder farmers are more likely to have limited access to farming and market information (Mutero, Munapo and Seaketso, 2016). However, by engaging in collective action, smallholder farmers can overcome these obstacles to successful commercialisation.

\subsection{Collective action and the question of trust}

Collective action depends on people's willingness to subordinate their narrow individual interests for communal ends, ostensibly in order to reap potentially greater benefits of a joint effort. The concept provides an analytical lens for studying organisational activities across multiple social contexts, from grassroots mobilisation to national and transnational organisation and coordination (Tilly, 1985; Valdez, 2011; Clément, 2015; Schulze-Cleven, 2017). Voluntary associations serve as important vehicles for collective action by bringing together different social groups and are, thus, considered vital to sustaining modern democratic societies and promoting income-generating activities among the poor (Putnam, 2000; Pfaff and Valdez, 2011).

In developing countries characterised by weak or inefficient state institutions and imperfect markets, collective action is understood to play an even more crucial role. In agrarian communities where failures of state and markets severely curtail access to roads, schools, health facilities, and potable water, grassroots organisations can enable community members to work together to overcome some of these problems. For instance, farmers can reduce costs by pooling resources to transport their goods to marketing centres or establishing savings schemes to compensate for lack of access to credit from formal financial institutions (Markelova et al., 2009). A recent review by Tirivayi et al., (2018) concludes that there is a strong potential for voluntary associations like forestproducer organisations to contribute to the expansion of access to social protection among underserved rural populations, through their provision of informal insurance and social services to community members. Consequently, collective action has been proposed as a viable pathway out of poverty for rural households.

Social capital is a crucial ingredient in any collective action scheme. It has been defined as the network of relationships among social actors, and the benefits that derive from these relationships (Portes, 1998; Aldrich 
and Meyer, 2015). Social capital enables communities to collectively mobilise to confront a range of material threats to lives and livelihoods (Warren, Thompson and Saegert, 2001; Adger, 2003), as well as problems arising from unequal institutional and power arrangements (Mwangi and Markelova, 2009). Social capital is crucial because it is 'the interdependence of agents through their relationships with each other' (Adger, 2003, p. 388) through which individuals and communities can effectively confront the threats to their livelihoods. Nevertheless, it is shaped by the structures of social relations in which it is embedded.

Studies on agrarian communities also show that social capital is associated with a variety of positive livelihood outcomes among smallholder farmers. A review of studies on agricultural productivity in Nigeria shows that farmers who participate in informal organisations have more access to informal credit and tend to have higher levels of productivity (Liverpool-Tasie, Kuku and Ajibola, 2011). Similar outcomes have been observed in Uganda, where households with higher levels of social capital are more likely to participate in collective farming and to exercise greater agency in market transactions. Moreover, social capital contributed to women's empowerment by bolstering their ability to accumulate assets and participate in collective decision-making (Abenakyo et al., 2008). In ecologically fragile contexts, social capital has been shown to be related to smallholder farmers' choice of different adaptive strategies in response to climate change (Yaméogo, Fonta and Wünscher, 2018).

Studies in Ghana have found that social capital can enable farmers to overcome individual constraints through increased access to social and material support (Wuepper and Sauer, 2016). Networks of trust within and between communities and other actors, like traders, government agencies, and aid organisations, have been shown to improve access to tractor-based mechanised farming among farmers in northern Ghana. By drawing on the resources inherent in their networks, some smallholder farmers are able 'first to purchase personal tractors and second, to gain timely access to tractor-hire ploughing services at the community level' (Kansanga, 2017, p. 718).

However, many other studies (see Cleaver, 2005; Offer, 2012; Koutsou, Partalidou and Ragkos, 2014; Fonte and Cucco, 2017) caution against both analytical and programmatic over-dependence on social capital to fill the gap left by market and state failure. In many places, participation in farmer groups for collective action remains low, owing to low levels of social capital (Koutsou, Partalidou and Ragkos, 2014). The strength and cohesiveness of associational life is predicated on the quality of interpersonal social relations (van Rijn, Bulte and Adekunle, 2012).

Trust is, thus, a very important, though often overlooked, element of social capital (Fu, 2004). Trust lays the foundation for cooperation and reciprocity (Siisianen, 1999). In fact, interpersonal trust is so important to the ongoing existence of networks that groups develop various mechanisms for monitoring behaviour and enforcing compliance to group norms. These mechanisms range in intensity from informal socialisation and ridicule on one extreme, to more severe actions like social ostracism and even banishment on the other (Portes and Sensenbrenner, 1993). Hence, the view that social capital is a blank cheque that members of a community can draw on at will with little or no expense to themselves is more romantic than realistic. Indeed, studies have shown that in some instances, entrepreneurs may prefer to escape whatever comforts or material supports their communities provide if they find the reciprocal expectations from the communities to be too onerous or constrictive (Portes, 1998; Asante, 2018).

This implies that social capital is not equally available to all members of a community. Since material resources are unequally distributed, the ability to engender and maintain trust will also be unequally distributed in any community. This situation puts resource-poor actors at a marked disadvantage, because their material circumstances predispose them to short-term economic calculations, which in long-term economic relationships, can place the other party at a disadvantage, and thus destroy the basis for subsequent cooperation. In fact, in some instances, adverse incorporation in social networks can trap the poorest in chronic poverty by forcing them to accumulate reciprocal obligations that absorb all disposable income and make it impossible for them to acquire assets or invest in income-generating activities (Hickey and Du Toit, 2013). 
This paper draws on qualitative data collected as a follow-up to the quantitative baseline survey conducted as part of the Ghana Work Stream 1 package of the APRA consortium in the Ahanta West and Mpohor districts of the Western Region (see Dzanku and Hodey, 2019 for more details on the quantitative design). Building on preliminary insights from the quantitative study, we sampled four communities based on the dominant marketing outlets identified in the quantitative data - i.e., commercial engagement with BOPP, NGL, B-BOVID, and independent sales (on the open market or to artisanal processors). We also selected a fifth community that combined all four commercialisation channels. The selected communities are Adum Dominase (BOPP), Butre (Independent), Kwesikrom (NGL), New Akwidaa (Mixed), Pretsea (B-BOVID). Farming is the main economic activity in these communities, but other activities like oil palm processing and tricycle transportation provide off-farm livelihood opportunities (see Table 3.1).

The quantitative study found differences among farmers based on their mode of participation in the oil palm economy. Upon harvest, farmers choose one or a combination of the following channels of market participation: (1) direct sales to OPCs, like BOPP and NGL; (2) sales to OPCs through agents or intermediaries; (3) independent sales on local market; and (4) processing own output. However, farmers differ in their ability to access the various commercialisation channels. For instance, those who sell directly to companies are more likely to have working capital, higher levels of education, and access to paved roads. On the other hand, those selling through intermediaries tend to have fewer options compared to the first group. Farmers who are not wealthy enough to sell directly to the companies, and are unwilling to engage with intermediaries, can sidestep the formal market altogether and instead sell to market women or process their own fruits. Own processing is almost as profitable as selling directly to the companies, but requires initial capital outlay which most farmers do not have (Dzanku et al., 2020, p. 15).

The qualitative follow-up further interrogated some of these findings. In each community, we sampled at least five heads-of-household. At the household level, we conducted interviews with each household head, which lasted for an average of one hour, and complemented these with shorter interviews with spouses and dependents. In our sample, female headsof-households tended to be divorced or widowed, hence there was no spouse to be interviewed. We also interviewed key actors in the oil palm economy in each community, including farm hands or workers, aggregators or buying agents, and artisanal processors. In each community, we also conducted key informant interviews with chiefs and other local leaders, such as unit committee chairs or assembly members. We conducted two FGDs separately for males and females in each community. At the district level, we conducted expert interviews with district agricultural officers of the MoFA in Mpohor and Ahanta West. Finally, we interviewed management level employees at BOPP, NGL, and B-BOVID. Fieldwork was conducted by a team of six field assistants and two supervisors, and lasted for two weeks. The data was subsequently transcribed and analysed using the Atlas.ti CAQDA. This paper largely draws on the farmer subsample of the qualitative data.

Table 3.1: Some characteristics of study communities

\begin{tabular}{|l|l|l|l|l|l|}
\hline District & \multicolumn{3}{|c|}{ Ahanta West } & \multicolumn{2}{c|}{ Mpohor (Wassa East) } \\
\hline Communities & New Akwidaa & Pretea & Kwesikrom & Adum Dominase & Butre \\
\hline $\begin{array}{l}\text { Dominant } \\
\text { marketing outlets }\end{array}$ & Mixed & B-BOVID & Norpalm & BOPP & Independent \\
\hline $\begin{array}{l}\text { Economic } \\
\text { activities (main) }\end{array}$ & $\begin{array}{l}\text { Farming (cassava } \\
\text { and oil palm), } \\
\text { fishing, tricycle } \\
\text { (transport) }\end{array}$ & $\begin{array}{l}\text { Farming (oil palm), } \\
\text { tricycle (transport) }\end{array}$ & $\begin{array}{l}\text { Farming (oil palm } \\
\text { and okra), tricycle } \\
\text { (transport) }\end{array}$ & $\begin{array}{l}\text { Farming (cocoa } \\
\text { and oil palm), } \\
\text { tricycle (transport) }\end{array}$ & $\begin{array}{l}\text { Farming (oil palm), } \\
\text { fishing, palm } \\
\text { oil processing, } \\
\text { tricycle (transport) }\end{array}$ \\
\hline
\end{tabular}

Source: Authors' own 


\section{ASSOCIATIONAL LIFE IN THE STUDY COMMUNITIES}

FBOs are crucial in the lives of farmers and farming communities. The literature (Koutsou, Partalidou and Ragkos, 2014; Tregear and Cooper, 2016; Fonte and Cucco, 2017; Kansanga, 2017; Wynne-Jones, 2017) suggests that FBOs play three major roles, namely: 1) education and information dissemination on improved farming practices and income generating activities; 2) mediation on issues such as access to credit, price-setting, and market access; and 3) conviviality and social support. However, whether or not a FBO performs these roles, and the extent to which it does, depends on a variety of factors. An important factor concerns the source of initiative in establishing the FBO. In the most recent survey of FBOs in Ghana, Salifu and Funk (2012) observe that almost 60 per cent of FBOs in Ghana were initiated externally, usually by agricultural extension agents (AEAs) who set them up to streamline their extension activities or to provide a vehicle through which farmers could receive support from government or non-governmental organisations (NGOs).

For smallholders who lack individual access to the resources necessary to participate in high-value markets, FBOs provide a means by which they may reap the benefits of agricultural commercialisation from which they may otherwise be cut off. In our study communities, these associations tend to be weak or non-existent. This often resulted from the inability of the organisations to deliver on the expectations of material or other support which the FBO's establishment had generated. Although they received training on good agronomic practices through their FBOs, the farmers complained that they are yet to see the benefit of these training programmes. For instance, they insisted that although they fully understood the importance of adhering to safety standards on their farms, they could not practically ensure this because they lacked the resources to procure protective materials such as boots, gloves, nose masks, and helmets. This is expressed by a female farmer as follows:

BOPP often sends some workers here to teach us how to do pruning and other activities.... They just say that, but give us nothing to do the pruning. They have taught us everything from cultivation, maintenance, harvesting and even carrying it to the roadside, but we have not received anything from them to date. (Female FGD, Adum Dominase, 24th April, 2019)

Associations could help farmers collectively overcome obstacles to productivity and, thereby, improve the livelihoods of households that participate in farmer organisations. An important obstacle to boosting productivity among smallholders is their inability to adopt or take advantage of mechanisation. While adoption of mechanisation may be out of the reach of individual farmers, they stand the chance of benefiting from collective mechanisation schemes (Kansanga, 2017). Findings from the quantitative survey (Dzanku and Hodey, 2019; Dzanku et. al., 2020) show that artisanal processing was more profitable and welfareenhancing than selling of raw fruits to either the OPCs or on the open market. Artisanal processing also helped farmers to prevent wastage (especially in peak seasons when the OPCs have more supply than needed), hedge against low prices, and to take advantage of increased prices in the lean season (Dzanku et al., 2020). However, owing to the weakness of FBOs in the study communities, there was virtually no collective effort in any of the study communities to collectively engage in artisanal processing.

Associations are also expected to negotiate for better prices and other incentives for producers (Fonte and Cucco, 2017). Farmers in the study communities had derived this benefit from their associations in the past, when their FBOs had mediated between them and outside organisations like the government or OPCs on issues such as pricing and sales arrangements. While much of this mediation had not happened in the study communities in recent years, many farmers asserted that they will be better off with collective action in pursuit of better prices, sales arrangements, access to credit and access to mechanisation in production and processing.

You know the kind of farming we do here we don't have any association that regulates things... People quote the price at which they want to buy your products. If you say you will not sell it to them it will go waste. So our work as farmers is sometimes very difficult. (Male farmer, Pretsea, 15th April, 2019) 
All oil palm farmers in Ghana can form an association and determine the price. We can have a negotiation with the company and get a fixed price that will apply to the sale of oil palm everywhere in Ghana. But we don't have that in this country. (Male FGD, Adum Dominase, 24th April, 2019)

Smallholder farming is greatly challenged by factors, such as access to credit, which hinder the development of agribusinesses. Measures to develop agriculture in Africa and elsewhere have placed access to credit at the centre, in the environment of strengthened farmer groups to share knowledge and improve the productive use of such credit facilities (Kasanga, 2017). Farmers attribute their inability to step up their productivity partly to the absence of strong associations:

...the farmers here do not have an association. If we had an association, we would have been able to push for some of these incentives because the government mostly listen to an organised group of people rather than an individual. (Female FGD, Butre, 25th April, 2019) 


\section{FACTORS SHAPING ASSOCIATIONAL QUALITY}

The failure of farmers in the study communities to collectively organise to solve the common problems that confront them can be explained by a number of factors, including the personal or financial cost of cooperation, unrealistic expectations of the FBOs, and mistrust stemming from poor internal governance. First, such associations thrive on members' financial contributions. However, due to the inability of some farmers to make such contributions, the activities of the association gradually come to a standstill, eventually leading to collapse. One such association in Adum Dominase collapsed partly because 'some members were not paying dues as they ought to' (Male farmer, Adum Dominase, $18^{\text {th }}$ April 2019). While many farmers genuinely lacked the means to pay, the fact that a large enough number of farmers defaulted on payment led to a free-rider problem, where even those who could afford to pay refused to do so because they believed others were not contributing their fair share. As another respondent in the same community bluntly put it, his association collapsed because 'some people wanted to reap off others' (Male farmer, Adum Dominase, 18th April 2019).

Similarly, collective decisions, such as a sales boycott meant to drive up prices, can sometimes impose a stiff financial cost on poorer farmers. Where such endeavours require the adherence of all involved to ensure success, poorer farmers become the weakest links. For instance, a collective decision in one of the communities to withhold their produce until the price improves was thwarted by poorer farmers who urgently need cash and could not stick to the agreement long enough:

We can agree to say we will accept the price at which the buyers buy our palm fruits, but someone in Yawkow would just go and accept the same [old] amount and we wouldn't even know. That would mean he is undermining the decision we had all agreed on (Male farmer, Kwesikrom, 20th April, 2019)

A second reason for the weakness of FBOs was the disparity between the high expectations that farmers had of receiving immediate material benefits, and the reality once they joined. The high expectations are partly due to the fact that most of these FBOs were initiated by external actors like AEAs, NGOs, government agencies or OPCs. Disillusionment at the failure of the associations to deliver the expected material rewards was a common theme in respondents' account of why their associations ultimately failed:

I think it collapsed because some members were not paying dues as they ought to. Also, members were disappointed in BOPP and the other NGOs as they were expecting support in terms of money, which was not coming. (Male farmer, Adum Dominase, 18th April, 2019)

Here, it is not common to see associations... associations do not survive here. Sometimes they tell us that they will bring farmers some things but nothing happens. (Male farmer, Butre, 23rd April, 2019)

This particular government brought some seedlings to us to cultivate with the promise that they will assist us in weeding around it, but this promise and others were not fulfilled. We have been working with our own strength all these years. They didn't even give us machetes and other tools to farm the oil palm. The same thing happened four years ago, they promised to bring farmers money that never came. All my children have left the house and my wife and I are too old to do all this work. (Male FGD, New Akwidaa, 23rd April 2019)

Moreover, associations were internally fragmented by mistrust bred by widespread suspicions of financial malfeasance by the executives. There appears to be no rigorous mechanism to stop exploitation by leaders of these associations. Respondents recounted numerous instances of blatant misuse of associations' resources, the most extreme example of which emerged during a focus group:

[All] that they said they will give to us, one Mr. B-, he was the head in this area, he took it all and squandered it. He committed suicide when the government began an audit. So all the benefits were lost to the farmers and we have had to rely on our individual resources since 2006. (Male FGD, New Akwidaa, 23rd April 2019) 
Such instances of malfeasance reinforce the alreadywidespread suspicion against any attempt at collective action. In a social context where collective action already imposes high costs on individual farmers, corruption and misuse of resources by FBO executives substantially dampens enthusiasm in associational life. There, thus, seems to be a general apathy among the farmers in matters of communal organisations, collective action, and associations.

\subsection{The importance of autonomy and trust}

As the above analysis suggests, economic relations between farmers tended to be more individualised than one would expect to find in rural communities. As one farmer put it when explaining the absence of a FBO in his community: '...there is no communication. Every farmer manages his own farm. We do not have any farmers' association that we belong [to here]' (Male farmer, Butre, 18th April, 2019). Lack of financial means is an important obstacle in many of these abortive endeavours at collective action in the study communities. Failure of members to meet financial obligations have often hindered the success of group efforts. In Kwesikrom, farmers decided to contribute towards the purchase of an oil palm processor for the community, which would have enabled them to derive higher incomes than selling the raw fruits. However, as one respondent explained (Male FGD, Kwesikrom, 23rd April, 2019), '... [some] people failed to pay the little contributions [needed to purchase a processing unit],' and the plan ultimately failed.

This situation further pushed farmers into increasingly atomised behaviour. Many farmers were tempted to explain this lack of cooperative spirit as a moral failure attributable to the character of individual farmers:

We are not really friends. We all concentrate and work individually, no cooperation whatsoever (Male farmer, Kwesikrom, 20th April, 2019)

I think it is the nature of us, the Ahanta people. We do not like each other. We like to be individualistic instead of coming together to do things as a unit. (Male farmer, Kwesikrom, 20th April, 2019)

However, the evidence in this paper points to the importance of structural factors, in particular a lack of economic autonomy, rather than personal moral shortcomings in explaining the failure of collective action in these farming communities. As the quantitative study which preceded this project found, farmers' 'lack of autonomy shapes whom they sell to, at what price, and under what conditions' (Dzanku et al., 2020, p. 19). Although they are aware of the benefits of nurturing social networks and collective action, the economic constraints they face lead them to prioritise short-term survival strategies. This point is illustrated in their explanation for why they sell their produce at undesirable prices when they can get a higher price by collectively bargaining and withholding their harvest:

That is the problem of farmers. If we all decide not to sell and we will find other means to feed our families, all these problems would have ended. It will not work if we cannot do that. (Male FGD, Adum Dominase, 24th April, 2019)

We cannot get anyone to buy [our oil palm] and no car comes here to buy it. You might have taken loans here and there so you will certainly give them the oil palm in order to raise money to offset the loan. (Female FGD, Kwesikrom, 24th April, 2019)

This lack of autonomy undermines their ability to generate or nurture trust. Without trust, FBOs lack any means of ensuring the implementation of collective decisions requiring voluntaristic compliance. The resulting mistrust further engenders disinterest and apathy in the affairs of the association. Moreover, mistrust exacerbates the personal cost of cooperation for poorer farmers who experience a number of overlapping disadvantages that make it unlikely for them to benefit from participation in communal associations and collective action (Cleaver, 2005). The inability to make regular monetary contributions, and the time the associations take from their productive activities, creates barriers to effective participation and probable future benefits.

The situation imposes what Offer (2012) calls a "burden of reciprocity' on the poor (see also Asante, 2018), who tend to lack the resources necessary to participate in the kinds of reciprocity that enable collective action. Specifically, poverty undermines the ability of individuals and households to maintain their social relations, which has negative implications on their ability to tap into the resources which could otherwise have been derived by participating in social support networks (Offer, 2012). This can result in a vicious circle where wealth disparities widen in a community because the material prerequisites for participating in livelihood-enhancing collective schemes end up excluding exactly those who need such schemes the most.

Even though efforts at collective action failed in the study communities, wealthier farmers were not as negatively affected as others. Some organised into smaller groups to sell directly to the OPCs. Such groups were more reliable than the FBOs because 
all members were able to meet the material cost of participation. For instance, better-off farmers are able to work together in a small group of similarly endowed farmers to meet the cost of transporting their produce to the company mills, thereby cutting out the aggregators or middlemen who offer lower prices than the companies.

I do not sell to agents. I sell directly to the companies. I was even awarded. I can show you my certificate. I have gotten so many awards. I got an award for the second best organiser of palm fruits. (Male farmer, Adum Dominase, April 19, 2019)

When we used to sell the oil palm to agents, we were not making much money, all that we got was used to pay the labourers and a few other things. But now that we sell to BOPP directly, we have taken the middleman's profit for ourselves. Through that, our living standard has improved a little. (Female farmer, Adum Dominase, April 18, 2019)

With these benefits, wealthier farmers are further disincentivised from participating in collective action, which in turn weakens associational life. Besides the costs associated with organising groups and collective action, experiences and stories of a free-rider problem in associations dissuade rich farmers to engage in collective action. In the end the rich are better off, and the poor farmers remain poorer. 


\section{CONCLUSION}

Ghana's highly commercialised oil palm value chain could catalyse national economic development, and provide a pathway out of poverty for smallholders engaged in the cultivation of the crop. However, this potential cannot be automatically realised, and studies Figure 6.1: Graphical presentation of argument suggest that wealthier smallholders or those with more asset holdings are better able to reap the benefits of agricultural commercialisation (Dzanku et al., 2020; Saha, Sabates-Wheeler and Thompson, 2021). For farmers without the material wherewithal to profitably

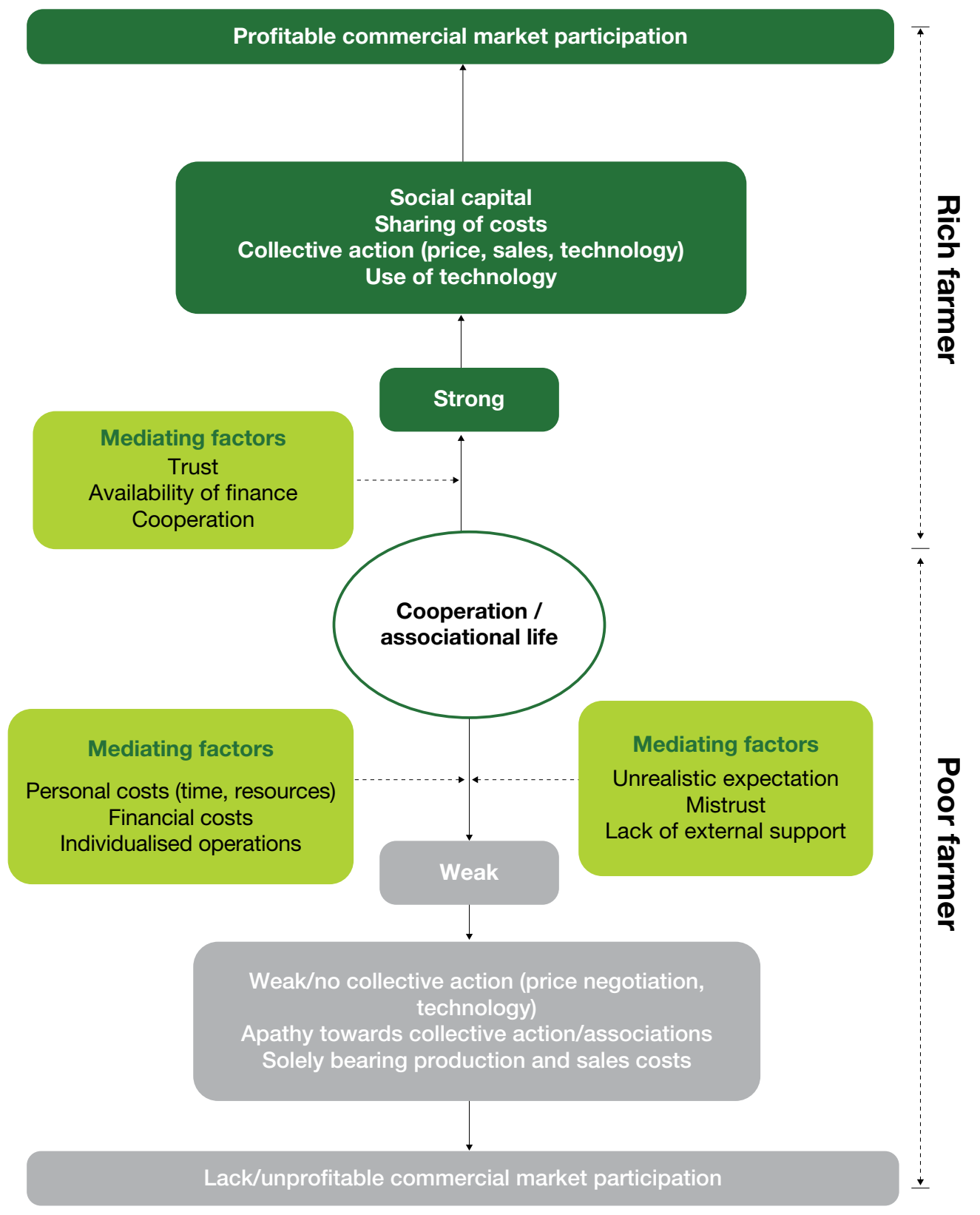

Source: Authors' own 
participate in agricultural commercialisation, engaging in collective action through FBOs could help them to overcome some of the obstacles to successful commercialisation. By participating in collective action schemes, smallholders could gain access to credit, improved inputs, or even networks of social support. There is a strong potential for voluntary associations to contribute to the expansion of access to social protection among underserved rural populations, through their provision of informal insurance and social services to community members (Markelova et al., 2009; Tirivayi et al., 2018). Thus, collective action is widely recognised as a viable pathway out of poverty for the agrarian poor.

However, poor farmers in our study communities lacked the ability to tap into the benefit expected to accrue from participation in collective action. In all five communities, FBOs were either weak or non-existent. Without any strong association, farmers are left with no organisational vehicle to collectively negotiate prices or acquire productivity-enhancing technology. Wealthier farmers are able to overcome this disadvantage by independently pooling resources with similarly endowed farmers to engage in income-enhancing activities, such as sharing the cost of direct sales to the OPCs or investing in processing technology (see Figure 6.1).

This situation is particularly disadvantageous for poorer farmers because it hinders their ability to benefit from the advantages of agricultural commercialisation. In particular, a strong association or cooperative could have enabled them to overcome the lack of resources which limits their individual abilities for profitable market participation. This assumption is based on analytical insights from the social capital literature (LiverpoolTasie, Kuku and Ajibola, 2011; Yaméogo, Fonta and Wünscher, 2018), which postulates that social networks contain a rich store of resources which can be tapped into to improve individual lives and empower communities. However, our findings indicate that a lack of material autonomy predisposes poor farmers to short-term decisions, which may undermine their ability to engage in long-term cooperative activities. This can result in a vicious circle in which wealth disparities widen in a community because the materials prerequisites for participating in livelihood-enhancing collective schemes end up excluding exactly those who need such schemes the most. 
Abenakyo, A., Sanginga, P., Njuki, J.M., Kaaria, S. and Delve, R.J. (2008) 'Relationship between social capital and livelihood enhancing capitals among smallholder farmers in Uganda, 2007 Second International Conference, August 20-22, 2007, Accra, African Association of Agricultural Economists (AAAE). Retrieved from www. ageconsearch.umn.edu/bitstream/52191/2/Abenakyo.pdf (Accessed: 20 January 2021)

Aldrich, D.P. and Meyer, M.A. (2015) 'Social capital and community resilience', American Behavioral Scientist 59(2): 254-269.

Arias, P., Hallam, D., Krivonos, E. and Morrison, J. (2013) Smallholder integration in changing food markets. Rome: Food and Agriculture Organization of the United Nations.

Asante, K.T. (2021) The Political Economy of the Oil Palm Value Chain in Ghana, APRA Working Paper 54, Brighton: Future Agricultures Consortium. Available at: https://opendocs.ids.ac.uk/opendocs/handle/20.500.12413/16677 (Accessed: 15 April 2021).

Asante, K.T. (2018) 'Strategic coethnicity: Social capital and entrepreneurial strategies of two Ghanaian migrant businesses', Journal of Enterprising Communities: People and Places in the Global Economy 12(4): 418-436.

Cazzuffi, C., Mckay, A. and Perge, E. (2020) 'The impact of agricultural commercialisation on household welfare in rural Vietnam', Food Policy 94, 101811. doi:10.1016/j.foodpol.2019.101811

Cleaver, F. (2005) 'The Inequality of Social Capital and the Reproduction of Chronic Poverty', World Development 33(6): 893-906.

Clément, K. (2015) 'Unlikely mobilisations: how ordinary Russian people become involved in collective action', European Journal of Cultural and Political Sociology 2(3-4): 211-240.

Diao, X., Silver, J. and Takeshima, H. (2016) Agricultural Mechanization and Agricultural Transformation. International Food Policy Research Institute (IFPRI) Discussion Paper 1527. Washington DC: IFPRI. Available at: https://ssrn.com/abstract=2778723 (Accessed: 20 January 2021).

Dorward, A. and Kydd, J. (2002) Locked in \& Locked Out: Smallholder Farmers \& the New Economy in Low Income Countries. Paper presented at the 13th International Farm Management Congress, National Sports and Conference Centre Papendal near Wageningen and Arnhem, 7-12 July.

Dzanku, F.M., Asante, K.T., Quarmine, W. and Hodey, L.S. (2020) Smallholder Farmers' Choice of Oil Palm Commercialisation Model and Household Welfare in South-western Ghana. APRA Working Paper 43. Brighton: Future Agricultures Consortium. Available at: https://opendocs.ids.ac.uk/opendocs/handle/20.500.12413/15714 (Accessed: 12 January 2021).

Dzanku, F.M. and Hodey, L.S. (2019) Oil Palm Commercialisation Models and Outcomes in South-Western Ghana: Draft Baseline Survey Report. Brighton: Institute of Development Studies (IDS), University of Sussex.

Fischer, E. and Qaim, M. (2014) 'Smallholder Farmers and Collective Action: What Determines the Intensity of Participation?', Journal of Agricultural Economics 65(3): 683-702.

Fonte, M. and Cucco, I. (2017) 'Cooperatives and alternative food networks in Italy. The long road towards a social economy in agriculture', Journal of Rural Studies 53: 291-302. 
Francesconi, G.N. and Ruben, R. (2007) Impacts of Collective Action on Smallholders' Commercialisation: Evidence from Dairy in Ethiopia. Paper prepared for presentation at the I Mediterranean Conference of AgroFood Social Scientists. 103rd EAAE Seminar 'Adding Value to the Agro-Food Supply Chain in the Future Euromediterranean Space'. Barcelona, Spain, 23-25 April.

Fu, Q. (2004) Trust, Social Capital, and Organizational Effectiveness. MA Dissertation, Virginia Polytechnic Institute and State University, Blacksburg, VA.

GGS (Ghana Statistical Survey). (2018) Ghana Living Standards Survey Round 7. Accra: GSS.

Hickey, S. and Du Toit, A. (2013) 'Adverse incorporation, social exclusion, and chronic poverty', in A. Shepherd and J. Brunt (eds.) Chronic Poverty: Concepts, Causes and Policy. (pp. 134-159). Palgrave Macmillan, London.

Kansanga, M.M. (2017) 'Who you know and when you plough? Social capital and agricultural mechanization under the new green revolution in Ghana', International Journal of Agricultural Sustainability 15(6): 708-723.

Kibirige, D. (2016) 'Smallholder Commercialization of Maize and Social Capital in the Social Capital in the Eastern Cape', International Journal of Economics, Commerce and Management 4 (9); 236-252.

Koutsou, S., Partalidou, M. and Ragkos, A. (2014) 'Young farmers' social capital in Greece: Trust levels and collective actions', Journal of Rural Studies 34: 204-211.

Liverpool-Tasie, L.S., Kuku, O. and Ajibola, A. (2011) Review of literature on agricultural productivity, social capital and food security in Nigeria. NSSP Working Paper 21. Washington DC: International Food Policy Research Institute.

Markelova, H., Meinzen-Dick, R., Hellin, J. and Dohrn, S. (2009) 'Collective action for smallholder market access', Food Policy 34(1): 1-7.

Mutero, J., Munapo, E. and Seaketso, P. (2016) 'Operational challenges faced by smallholder farmers: a case of Ethekwini Metropolitan in South Africa', Environmental Economics 7(2): 40-52. Available at: http://dx.doi. org/10.21511/ee.07(2).2016.4 (Accessed: 6 February 2021).

Mwangi, E. and Markelova, H. (2009) 'Collective action and property rights for poverty reduction: A review of methods and approaches', Development Policy Review 27(3): 307-331.

Nyikahadzoi, K., Siziba, S., Sagary, N., Njuki, J. and Adekunle, A.A. (2011) 'Promoting Effective Collective Marketing in the Context of Integrated Agricultural Research for Development in Sub Saharan Africa', Learning Publics Journal of Agriculture and Environmental Studies 2(1): 82-97.

Offer, S. (2012) 'The burden of reciprocity: Processes of exclusion and withdrawal from personal networks among low-income families', Current Sociology 60(6): 788-805.

Pfaff, S. and Valdez, S. (2011) Collective Action, in H. Anheier and S. Toepler (eds.) International Encyclopedia of Civil Society. New York: Springer-Verlag: 498-503.

Portes, A. (1998) 'Social capital: Its origins and applications in modern sociology', Annual Review of Sociology 24(1): $1-24$.

Portes, A. and Sensenbrenner, J. (1993) 'Embeddedness and immigration: Notes on the social determinants of economic action', American Journal of Sociology 98(6): 1320-1350.

Poulton, C. (2017) What is Agricultural Commercialisation, Why is it Important, and How do we Measure it? APRA Working Paper 6, Brighton: Future Agricultures Consortium. Available at: https://opendocs.ids.ac.uk/opendocs/ handle/20.500.12413/13560 (Accessed: 12 January 2021).

Putnam, R.D. (2000) Bowling alone: The collapse and revival of American community. New York: Simon and Schuster.

Saha, A., Sabates-Wheeler, R. and Thompson, J. (2021) 'Insights into smallholder capacity for agricultural commercialisation: Evidence from four African contexts', The European Journal of Development Research 1-46. Available at: https://doi.org/10.1057/s41287-021-00414-z (Accessed: 20 July 2021). 
Salifu, A. and Funk, R. (2012) Farmer Based Organizations in Ghana: How Are They Established and What Do They Do? Note 1. IFPRI: Ghana Strategy Support Programme.

Schulze-Cleven, T. (2017) 'Collective action and globalization: Building and mobilizing labour power', Journal of Industrial Relations 59(4): 397-419.

Siisianen, M. (1999) 'Voluntary associations and social capital in Finland', in J. VanDeth, M. Maraffi, K. Newton and P. Whiteley (eds.), Social Capital and European Democracy. London: Routledge.

Teye, J.K. and Torvikey, D. (2018) The Political Economy of Agricultural Commercialisation in Ghana: A Review, APRA Working Paper 15, Future Agricultures Consortium. Available at: https://opendocs.ids.ac.uk/opendocs/ handle/20.500.12413/13953 (Accessed: 8 May 2020).

Tilly, C. (1985) 'Models and realities of popular collective action', Social Research 52(4): 717-747.

Tirivayi, N., Nennen, L., Tesfaye, W. and Ma, Q. (2018) 'The benefits of collective action: Exploring the role of forest producer organizations in social protection', Forest Policy and Economics 90: 106-114.

Tregear, A. and Cooper, S. (2016) 'Embeddedness, social capital and learning in rural areas: The case of producer cooperatives', Journal of Rural Studies 44: 101-110.

Valdez, S. (2011) 'Subsidizing the cost of collective action: International organizations and protest among polish farmers during democratic transition', Social Forces 90(2): 475-495.

van Rijn, F., Bulte, E. and Adekunle, A. (2012) 'Social capital and agricultural innovation in Sub-Saharan Africa', Agricultural Systems 108: 112-122.

von Braun, J. (1995) 'Agricultural commercialization: Impacts on income and nutrition and implications for policy', Food Policy 20(3): 187-202.

Warren, M.R., Thompson, J.P. and Saegert, S. (2001) 'The role of social capital in combating poverty', Social Capital and Poor Communities 3: 1-28.

Wynne-Jones, S. (2017) 'Understanding farmer co-operation: Exploring practices of social relatedness and emergent affects', Journal of Rural Studies 53: 259-268.

Wuepper, D. and Sauer, J. (2016) 'Explaining the performance of contract farming in Ghana: The role of selfefficacy and social capital', Food Policy 62: 11-27.

Yaméogo, T.B., Fonta, W.M. and Wünscher, T. (2018) 'Can social capital influence smallholder farmers' climatechange adaptation decisions? Evidence from three semi-arid communities in Burkina Faso, West Africa', Social Sciences 7(3): 33. 
Takyiakwaa, D., Tetteh, P.S.K. and Asante, K.T. (2021) Explaining the Weakness of Associational Life in Oil Palm Growing Communities in Southwestern Ghana, APRA Working Paper 68, Brighton: Future Agricultures Consortium

(c) APRA 2021

ISBN: 978-1-78118-857-6

DOI: 10.19088/APRA.2021.028

\section{(cC) BY-NC-ND}

This is an Open Access report distributed under the terms of the Attribution-Non Commercial-No Derivs 4.0 Unported (CC BY-NC-ND 4.0) Attribution - You must give appropriate credit, provide a link to the license, and indicate if changes were made. You may do so in any reasonable manner, but not in any way that suggests the licensor endorses you or your use. NonCommercial — You may not use the material for commercial purposes. NoDerivatives - If you remix, transform, or build upon the material, you may not distribute the modified material. You are free to: Share - copy and redistribute the material in any medium or format.

https://creativecommons.org/licenses/by-nc-nd/4.0/legalcode

If you use the work, we ask that you reference the APRA website (www.future-agricultures.org/apra/) and send a copy of the work or a link to its use online to the following address for our archive: APRA, Future Agricultures Consortium, University of Sussex, Brighton BN1 9RE, UK (apra@ids.ac.uk)

All APRA Working Papers go through a review process before publication.

\section{@creative}

\section{DO YOU HAVE COMMENTS ON THIS PAPER?}

We would welcome your feedback on this working paper!

To provide brief comments, please follow this link to our short APRA Working Paper Feedback form: https://goo.gl/forms/1iVnXhhrIGesfR9

Agricultural Policy Research in Africa (APRA) is a programme of the Future Agricultures Consortium (FAC) which is

generating new evidence and policy-relevant insights on more inclusive pathways to agricultural commercialisation in sub-Saharan Africa. APRA is funded with UK aid from the UK Foreign, Commonwealth \&

Development Office (FCDO) and will run from 2016-2022.

The APRA Directorate is based at the Institute of Development Studies (IDS), UK (www.ids.ac.uk), with regional hubs at the Centre for African Bio-Entrepreneurship (CABE), Kenya, the Institute for Poverty, Land and Agrarian Studies (PLAAS), South Africa, and the University of Ghana, Legon. It builds on more than a decade of research and policy engagement work by the Future Agricultures Consortium (www.future-agricultures.org) and involves more than 100 researchers and communications professionals in Africa, UK, Sweden and USA. 